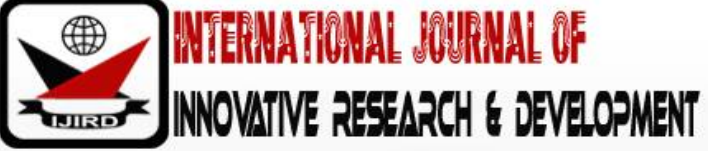

ISSN 2278 - 0211 (Online)

\section{Investing in the Education of Children for Better Returns: A Case of Community Secondary Schools at Bariadi District in Simiyu Region, Tanzania}

\author{
Estomih Moses Makyara \\ Ph.D. Student, Mwenge Catholic University, Tanzania
}

\begin{abstract}
:
The study was conducted at Bariadi, Simiyu region in Tanzania to ascertain the importance of investing in education for better returns. Selection of the area of study was based on the unique characteristics of the community to neglect investing in education of their children because of having no good examples of those who benefitted from education. This problem led to have communities that live in extreme poverty. When the government of Tanzania declared to provide free basic education for early eleven years, some members of the community, and particularly parents, leave the entire responsibility of education funding on the hands of the government. It was established that, in average, in every month, each student is allocated with Tshs 2,343/ = which is equivalent to one USD. The study applied non-probability sampling. Purposive sampling was then used to collect data from head of schools to respond to the prepared instrument (questionnaires) that aimed at identifying amount of funds released by the government every month and determine whether they sufficed for daily operation in the school or not. This technique was used to obtain fifty percent of schools to be included in the study by simple random sampling with replacement. Data collected was analyzed and then conclusion was made through that analysis. The findings indicated that the more one invests in education, the more affluence one becomes. Community and the government need to invest wisely in education for better returns. Spill-over effects on the investment in education were seen in the entire community when educated people influence their community in various ways of life.
\end{abstract}

Keywords: Capitation grants, basic education, social benefits, spill-over benefits, cost-sharing

\section{Introduction}

Investing in education is one of the best choices that people and societies may ever make. With the fact that education empowers its beneficiaries with skills, knowledge and potentials, these ultimately turn into tangible personal and social capitals that accrue health and socio-economic status (Murray, 2007).

Makyara, Semali, Lyamtane and Ogoti (2019) are in opinion that, the difference between and among nations economically is an attribute of how that nation has invested in the education of her people. Even at an individual level, significant differences economically, are seen between those who invested heavily and wisely in education as compared to those who do not.

There are considerable monetary returns accruing to individuals investing in education as suggested by Sianesi and Reenen, (2003). Returns to investment in education are not only on private but also there are full returns to society if education has the characteristics of public good as acknowledged by Harmon, Oosterbeek and Walker, (2002). In other words, the benefits of individually acquired education may not be restricted to the individual but must 'spill over' to other individuals in the same firm, industry, city, region or economy.

There is a linkage between education and national economic performance (UNESCO, 2006) hence for any society to develop and prosper education is embraced as a key. Education is therefore considered as a social investment since its social and spillover benefits outweigh what individuals gain as private returns (Galabawa, 2005). Therefore, these positive externalities from education (Hall, 2006) are the prime justification as to why societies and governments should continually invest more in education.

Education is a driving force to economic growth (Cattan \& Crawford, 2013) and therefore policy makers ought to acknowledge its benefits. In fact, although education increases the wages, prosperous, wealth and health of its beneficiaries in terms of private returns, education has external returns that reach others in terms of externalities or spillovers. These educational externalities also known as spill-overs constitute what is termed as public benefits of education because they benefit existing and forthcoming generations in terms of democracy, human rights, better governance, trade, political stability, longevity (Sackey and Harry, 2008) among others.

Education has an important role in transforming a nation's living standards. The educational outcomes are directly linked to labour market productivity and human capital accumulation, which directly contribute to shaping the 
future of a nation in the long run (Awaworyi and Mishra, (2014). However, owing to variation in socio-economic conditions, labour market opportunities, economic conditions and the availability of educational infrastructure, the returns to education vary significantly between nations and across time periods.

Educational investments lead to substantive spill-over benefits or externalities. Spill-over benefits of education implies what the surrounding community copy, learn and gain from an educated person ((Gieyoung and Chong, 2013). This may be reflected in various ways of life including wealth, health, feeding and living conditions among others. Such benefits overflow to other people other than single educated individuals or their families (Sianesi and Raenen, 2003). In other words, educational returns diffuse to reach even other members of society.

When governments and parents invest a lot in education, it is because they want to see the returns in that investment in terms of academic performance and different capabilities related to what they can do in their communities. As asserted by Makyara et al (2019), there are noted social benefits including existence of human rights, democratic societies, social cohesiveness, healthy citizens, people who can think out-of-the-box and critical thinkers among others.

In Europe, a study carried out by Greenfield, Quiroz, Rothstein-Fisch, and Trumbull, (2003) has concluded that there is a positive correlation between education and social cohesion. Specifically, in Germany as Sianesi and Raenen (2003) assert, the positive externalities have always been the striking reason that the government presents as justifications during the allocation of funds to the educational system.

Babyegeya (2002) and Schultz, (1963) argue that, investing in education is expected to breast the future productivity of people and, therefore, to boost the national income. Back in 1924, the Soviet Union educationalist called Strumlin argued that the labor productivity of a person with four years education exceeds that of an illiterate person by 43 per cent, and the labor provided by a person with secondary education is sixty times more than the labour of illiterate person. The more education individuals acquire, the better they are able to absorb new information, acquire new skills, and familiarize themselves with new technologies.

In Africa, the social and spill-over benefits are also known and valued. It is in this respect for instance that in Senegal, educational investments are gauged in terms of increase in productivity, spread of knowledge, organizational strength and people's openness to international scene (Sackey, 2008). In Ethiopia, the social and spill-over benefits of education are exceptionally valued to the extent that since the early 1990's there are no charges levied on students who enroll for higher education (Chapman, 1999).

\subsection{Statement of the Problem}

Returns on personal investment is an important factor affecting the decision to invest in education. In making any choice, an "economic person" will weigh the pros and cons to see whether there is gain or loss (Zhang, 2014). A decision to invest in education assumes there will be a good future return on the investment.

Experiences on three African countries (Ghana, Kenya and Rwanda) as noted by Ampofo, Bizimana, Ndayambaje, Karongo, Lyn, Lawrence, and Orodho, (2015) contend that investment in education is not a matter of random choice but rather an imperative led by the fact that education holds returns and externalities to the largest society. The authors reviewed theory of human capital, local and international publications on social and spill over benefits of education.

Nations, parents and individual learners invest in education not only because of financial gain. There are also social and cultural benefits, for instance; making friends, learning social rules and norms and understanding civic roles. But some of the most sought-after benefits from education are economic. Specialized knowledge and technical skills, for example, lead to higher incomes, greater productivity and generation of valuable ideas.

The area of study represents other rural areas in the country where every year the government invests a lot of funds but still the life style of the people does not change substantially. Poverty still exists while investment is also done. When there is no laudable policy for investment in education that will involve everyone in the society, government alone cannot provide everything required in the delivery of basic education which is compulsory therefore, expectations are not adhered to and students fail to acquire capabilities meant to fight against poverty.

Review of literatures indicates that investing in education of children is of paramount importance and this has been verified through many studies. Yet, there is no study among the reviewed studies on returns to investment in the education and its spill-over effects to the surrounding societies in rural Tanzania. Therefore, the problem understudy, investing in the education of children for better returns, a case of community secondary schools at Bariadi district in Simiyu region, Tanzania is determining to find out means to which investment in the education of children can bring forth intended outcome.

\section{Review of Empirical Studies and Government Commitment to Invest in Education}

Ensuring access to education for Tanzanian children has always been central to the government policy since independence. National development plans and policies have focused on education to increase productivity and growth as acknowledged by Suleman and Rakesh, (2017). Tanzania's commitments and efforts towards education have further been strengthened by global initiatives that have recently taken place.

To ensure that basic education is free for all children, in 2015 the government of Tanzania issued a circular which directs public bodies to provide free basic education to all students. Basic education constitutes early eleven years of education from pre-primary to secondary education (ordinary level). This includes the removal of all forms of fees and contributions. The Circular reads:

"Provision of free education means pupils or students will not pay any fee or other contributions that were being provided by parents or guardians before the release of new circular" (URT, 2015). 
From December 2015 to June, 2019 the government of Tanzania managed to release funds amounting Tshs 859,021,392,439.64 direct to Primary and Secondary schools all over the country as indicated in Table 1.

\begin{tabular}{|c|c|c|}
\hline & Period & Amount (Tshs) \\
\hline 1 & December 2015 - June, 2016 & $109,994,981,000.00$ \\
\hline 2 & July 2016 - June 2017 & $249,696,468,572.28$ \\
\hline 3 & July 2017 - June 2018 & $249,664,971,433.68$ \\
\hline 4 & July 2018 - June 2019 & $249,664,971,433.68$ \\
\hline & Grand Total & $859,021,392,439.64$ \\
\hline
\end{tabular}

Table 1: Summary of Funds Released by Tanzanian Government to Primary and Secondary Schools from December, 2015 - June, 2019

Source: BEMIS, 2019

Release of these funds was meant to reduce the burden carried by poor parents who could not bear the direct cost of education (through cost-sharing) to their children, ultimately, resort to drop out from education system. It is expected that; this government concern should bear intended educational outcomes. When such investment is incurred by the government, yet some students for their own reasons don't turn up for school that investment becomes what Galabawa (2005) term as white elephant or blind alley.

Table 2 depicts the amount of funds release by the government to secondary schools in the area of study (Bariadi Town Council) in 2016/ 2017 and 2017/ 2018 financial years. A total amount of Tshs 743,301,362.00 was released in these two years to show its commitment in adhering to fee-free education policy for sustainable education development.

\begin{tabular}{|c|c|c|}
\hline Type & $\mathbf{2 0 1 6 / 2 0 1 7}$ & $\mathbf{2 0 1 7 / 2 0 1 8}$ \\
\hline Capitation & $119,081,178.00$ & $71,992,308.00$ \\
\hline Fee compensation & $119,184,616.00$ & $109,075,446.000$ \\
\hline $\begin{array}{c}\text { Responsibility Allowances to } \\
\text { Heads of schools }\end{array}$ & $42,000,000.00$ & $42,000,000.00$ \\
\hline Food for boarding students & $103,430,976.00$ & $138,011,416.00$ \\
\hline Total & $382,222,183.00$ & $361,079,179.00$ \\
\hline
\end{tabular}

Table 2: Funds Released by the Government Direct to Schools In Bariadi Secondary Schools as Investment in Education in 2016/ 2017 and 2017/ 2018 Financial Years

Source: Bariadi Town Council Financial Statistics, 2019

The abolition of fees however, is not a panacea. As noted by Suleman and Rakesh, (2017), while cost is a major barrier to enrolment, evidence from country experiences is showing that, it alone does not determine the demand for education and that other factors need to be addressed if the gains made are to be consolidated and sustained. Regardless of school fee abolition, the indirect cost (i.e., opportunity cost) of school attendance would remain substantial.

Makyara, et al (2019) asserts that, education should be made a serious agenda and teaching and learning should also focus on that seriousness. If we want our education to bring forth returns, we need every one in our societies to make sure that education is given priority before anything else. In Tanzania, and in almost all nations of the world, basic education is compulsory in enrolment and attendance. Every child is afforded free access to education and parents are required to make sure that their children attend school until they complete the cycle of education to which one is enrolled.

\section{Research Design}

The study is quantitative where it explored data of education funding from schools. Quantitative methods involve the processes of collecting, analyzing, interpreting, and writing the results of a study (Creswell, 2012). Specific methods exist in both survey and experimental research that relate to identifying a sample and population, specifying the strategy of inquiry, collecting and analyzing data, presenting the results, making an interpretation, and writing the research in a manner consistent with a survey or experimental study. Data was collected through review of different documents and by using questionnaires disseminated to head of schools who are accounting officers and custodians of school funds from various educational stakeholders then analyzed according to the nature of the data.

\subsection{Target Population}

Population is the larger group from which the sample will be selected (Leedy \& Ormrod, 2001). According to Kothari (2012), population is the people that a researcher has in mind from whom he/ she can obtain information. Creswell (2012) defines population as a group of individuals who have the same characteristic.

Bariadi district which is in Simiyu region, Tanzania was sampled for the study. During the time of study, the district had only 16 secondary schools, of which eight schools $(50 \%)$ were included in the study. The population of this study comprised all secondary schools and educational funders including the central government, local government, nongovernment organizations who provide assistance to education, institutions and individuals (parents and non-parents). 


\subsection{Sample and Sampling Procedures}

The study applied non-probability sampling. Non-probability sampling is that sampling procedure which does not afford any basis for estimating the probability that each item in the population has a chance of being included in the sample (Kothari, 2012). Purposive sampling was then used to collect data from head of schools to respond to the prepared instrument (questionnaires). This technique was used to obtain fifty percent of schools to be included in the study by simple random sampling with replacement. The researcher prepared pieces of papers with names of all 16 secondary school and then put them in a box. He then picked those pieces of paper one after another and noting down their names until eight schools were obtained.

A question that often plagues novice researchers as stated by Cohen, Manion and Morrison (2005) is just how large their sample for the research should be. There is no clear-cut answer, for the correct sample size depends on the purpose of the study and the nature of the population understudy. Kothari (2012) is in opinion that optimum sample size is one which fulfills the requirements of efficiency, representativeness, reliability and flexibility.

Borg and Gall (1997:195) suggest that, as a general rule, sample size should be large when there are many variables, only small differences or small relationships are expected or predicted, the sample will be broken down into sub-groups, the sample is heterogeneous in terms of the variables understudy, and reliable measures of the dependent variables are unavailable. Oppenheim (1992: 44) adds to this the view that the nature of the scales to be used also exerts an influence on the sample size.

\subsection{Description of Data Collection Instruments}

The study used questionnaires to collect data pertaining to investment in education specifically at secondary school level. The questionnaires were used to acquire information from head of schools. The respondents to questionnaire by the virtue of their positions control every fund disbursed in their schools from different sources. By the use of regulations disseminated to them from fund providers, they make expenditure to fulfill school requirement. Data was also collected through the review of documents. Documents reviewed included Education policy, Basic Educational Management Information System (BEMS), education circulars and regulations, and educational statistics related to the study.

The questionnaires include both closed-ended and open-ended questions. Open-ended questions were designed in a way that could offer an opportunity for respondents to freely give their perceptions and opinions on how investment in education can lead to have learned societies who can contribute to the wellbeing of themselves and to the community to where they live.

\subsection{Description of Data Analysis Procedures}

Data was analyzed and put in a table for easy interpretation to find total amount of funding. Descriptive data was synthesized to form justification when compared from one instrument to another. During the process of questionnaire preparation, coding of questions was done to avail the computation of results. Data collected were edited and classified where required in order to facilitate tabulation.

\section{Findings}

Through data collected from questionnaires and document review, it was noted that there are noted benefits accrued from investment in education. Due to the prevailing education policy, the major funder of education at this level (secondary schools) is the government of Tanzania (URT: 2015). The past experience indicated that, before commencement of the new free basic education policy which came into operation in January 2016, education was partially funded by the government but also, parents were compelled to incur stipulated cost sharing of which there was no uniformity. Each school introduced an amount to be paid depending on school's priorities.

With minimal income, the community secondary schools were in worse condition because the parents and members of the community failed to contribute towards modernizing their school infrastructure. Cost sharing in education compelled some students drop out from education system but also to have dilapidated infrastructure with few students because of failure to pay school fees and other contributions. Essentially, free basic education increased enrolment and attendance gradually. The area of study had low enrolment, attendance and completion rates. In 2015, there was an enrolment of 1,536 form one students, in 2016 enrolment increased to 1,771. There was a slight increase of only 10 students in 2017 where the number reached 1781, in 2018 the number increased to 2,499 while in 2019, enrolment shot to 3,200 students as indicated in Table 3. There was also an increase of infrastructure in terms of classrooms, laboratories and desks to mention a few. These increases were facilitated by the investment done through free education.

\begin{tabular}{|c|c|c|c|}
\hline Year & Enrolment & Increase & \% Of Increase \\
\hline 2015 & 1,536 & N/A & N/A \\
\hline 2016 & 1,771 & 235 & 15.3 \\
\hline 2017 & 1,781 & 10 & 0.6 \\
\hline 2018 & 2,499 & 718 & 40.3 \\
\hline 2019 & 3,200 & 701 & 28.1 \\
\hline Total & 10,787 & 1,664 & \\
\hline
\end{tabular}

Table 3: Form One Enrolment from 2015 - 2019

Source: Education Department, Bariadi (2019) 
The increase in enrolment did not match with the resources available. The circular of free education made parents and some members of the community to resist any idea of investing in education with a notion that, the government has shouldered all the burdens of education funding. Although the parents, community and local governments were required to have their roles in the whole process of education funding, it is only the central government that showed commitment to release funds to schools on monthly basis. Parental involvement in the education of their children was of paramount importance in order to stock up where the government failed to meet all the needs of schools.

When there is high investment in education either by a nation or by an individual, there are noted returns to such investment as noted in Figure 1. There are social and private returns to education. An individual benefit from direct earnings when one gets employment or manages to create employment to himself and to others. Those with higher education and needed skills in the labor market, earn higher income more than those with less. On the other hand, the communities, from which the majorities are well educated, especially in most areas of urban centres, have schools that can deliver quality education where learning environment is also conducive. There are noted healthy population, democratic societies, modern houses and availability of other social services including water, electricity, roads, health centers which are in favorable conditions.

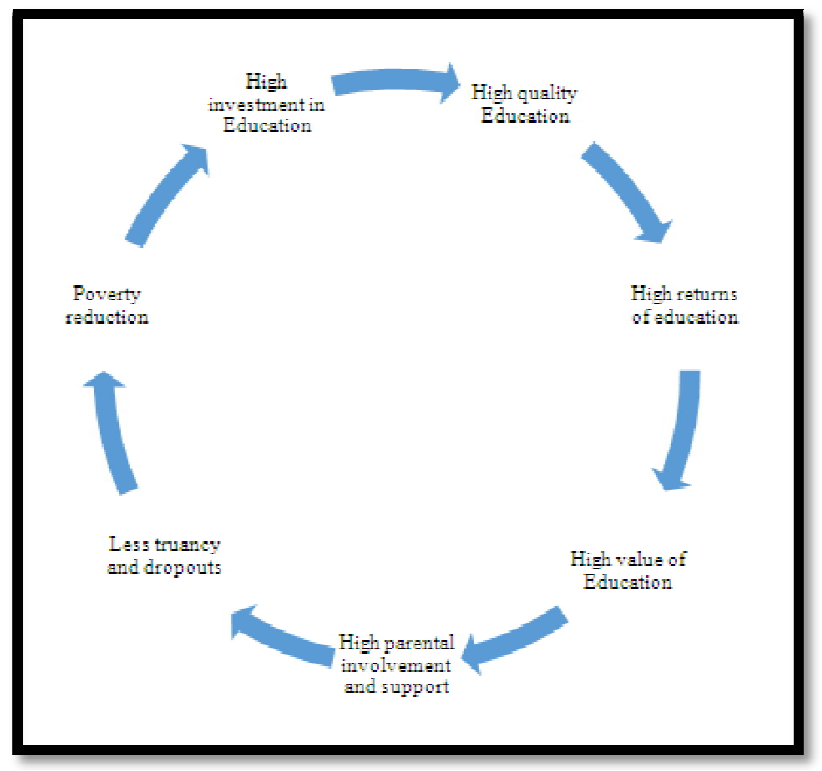

Figure 1: Investment in Education and Its Consequences

On the other hand, when there is low investment, there is also low-quality education which leads to low returns in education. When there are less returns in education, leads to low value of education and less parental support and involvement. This again, leads to truancy and dropout then poverty perpetuation. Poverty perpetuation will then lead to low investment in education.

Acquisition of knowledge and skills in less educated societies with poor school infrastructure is minimal. When parents cannot contribute to the well-being of their schools and when they are reluctant to participate in their schools' development, that society remain poor with many lawbreakers, sick people suffering from diseases that could be cured easily though application of healthy instructions. In the end, the government is compelled to carry a heavy burden of buying extra medicine to treat her people. It is expensive to be educational poor to an individual and to the government.

Reluctance to be involved in education of their children was said to emanate from past experiences especially when graduates failed to show relevant capabilities to solve social and economical problems in their societies. A form four graduate was required to be competent educationally but also work independently in the society without relying too much to those who have no secondary education. Inefficiency of graduates was an accumulation of poor education accelerated by non-compliance to proper investing in education.

It was noted that, funds disbursed to schools are spent for various purposes including cater for examination expenses, buying drugs for students, doing minor maintenances, buying laboratory chemicals and equipment, allowances for head of schools and paying for other personnel who are not paid directly by the government including security guards (URT, 2015). Every school was in short of infrastructure especially in the areas of classrooms, desks, teachers' houses and toilet pits.

In average, every month, each student is allocated with Tshs 2,342/ = which is equivalent to one US Dollar. According to responses from head of schools, this amount did not suffice the requirement of all undertakings in the school. In this way, some activities were not properly utilized. They suggested having other means to assist their schools to have adequate financial resources including members of the community to participate in contributing towards development of their schools.

It was suggested to invest in constructing dormitories at each school in order to assist students who stay far from school to get easy access to education. The district is broad, and there is one secondary school in each ward where some students are compelled to travel about eight to ten kilometers to and from school every day. In such a distance, some 
students (boys and girls) may find it difficult to attend school regularly. This situation forces girl students become more vulnerable to harsh environment and then drop out from school.

\section{Conclusions}

Based on the findings, the study had drawn few conclusions. In order to have effective investment in education, the government should stipulate initial running cost of a school regardless the size, and then release operational funds basing on the number of students available. It was revealed that, schools with few students get little amount of funds that do not suffice the costs of running the school hence fail to provide the curriculum properly due to lack of resources.

There should be a common way of involving the entire community to contribute towards development of a school in their societies. This is because; there are spill-over effects to the society when most of its members are well educated. Social and private returns to investment in education surpass the investment made. For example, where the society invests in the construction of a multipurpose hall at school, that hall can be used for social activities in the village including meetings and ceremonies of which everyone will benefit from it. Moreover, an educated society that is also economically stable can decide to contribute to the wellbeing of its school with fewer struggles.

A society well educated in most of the time is democratic, human rights are observed, and rule of laws is exercised. The people are healthy, diseases are minimal, and therefore, instead of having high budgets on heathy facilities including medicine, the government spends less in that area and allocates those funds in other development undertakings. Healthy people who are educated earn much for themselves and spill-over to the surrounding community.

While the government is committed to disburse operational funds to schools each month, teachers suggested having involvement of parents who will make keen follow-up to ensure their children attend school regularly. This suggestion was made due to the fact that, some students become truant and then drop out from school before completing that cycle of education. With truancy, maximization of government funds is not adhered to.

\section{Recommendations}

More research on the private and social benefits of schooling is needed. It is recommended to have studies on returns to investment in education at the communities that seem to prefer other traditions to education. Examples can be given to ascertain such returns as seen in the communities including being social, democratic, lack of communicable diseases, but also, gaining economic power. An educated community is seen to be cohesive when they plan together and implement what was agreed upon. These and many other examples of returns to investment in education can attract others to invest in the education of their children.

It was recommended that, the secondary school curriculum should involve entrepreneurship and agricultural studies. The necessity of these topics comes from the truth that the majority of secondary school graduates have no life skills to enable them work independently. This is because secondary education is too theoretical which does not reflect the real life in the society. Eventually, leads to some of secondary school graduates fail to work independently and continue to depend on their parents even at the age when one is supposed to be innovative and work independently.

There is a need for the nation to set a policy on how individuals, institutions, companies, local and central governments, non-governmental organizations and everyone in the society to be involved in funding education. For example, where there is a company in a certain area which is profit oriented, the profit so gained should be calculated and certain percentages of its profit should be directed towards development of the schools in the area.

\section{References}

i. Ampofo, S. Y., Bizimana, B., Ndayambaje, I., Karongo, V., Lyn, J., Lawrence, K. \& J. A. Orodho, J. A. (2015). Social and Spill-Over Benefits as Motivating Factors to Investment in Formal Education in Africa: A Reflection around Ghanaian, Kenyan and Rwandan Contexts. Journal of Education and Practice, Vol. 6, No. 11, 2015. Kenyatta University, Kenya.

ii. Awaworyi, S. \& Mishra, V. (2014). Returns to education in China: A meta-analysis. Discussion paper 41/ 14, ISSN 1441-5429, 2014.

iii. Babyegeya, E. (2002). Educational planning and administration. Dar es Salaam. The Open University of Tanzania.

iv. Borg, W. R. \& Gall, M. D. (1995). Educational research: An introduction. New York. Longman.

v. Cattan, S. \& Crawford, C. (2013). The impact of free, universal pre-school education on maternal labour supply. Institute for fiscal studies. Economic and social research council.

vi. Chapman, D. W. (1999). Teachers' incentives in the third world. Teaching and teacher education, Vol. 9, No. 3.

vii. Chukwu, L., Eze, T. \& Agada, F. (2016). Availability of instructional materials at the basic education level in Enugu educational level of Enugu State, Nigeria. Journal of Education and Practice, Vol. 7 No. 12, 2016.

viii. Cohen, L., Manion, L. \& Morrison, K. (2005). Research methods in education. London. Routledge Falmer.

ix. Creswell, J. W. (2012). Educational research: Planning quantitative and qualitative research, 4th Ed. Lincoln. University of Nebraska.

x. Galabawa, J. C. J. (2005). Returns to investment in education: Startling revelations and alternatives before Tanzanians. Dar es Salaam. University of Dar es Salaam.

xi. Galabawa, J. C. J. (2001). Education and the economy. Dar es Salaam. University of Dar es Salaam.

xii. Gieyoung, Lim. \& Chong, Kim. (2018). Minimum Wage and Unemployment: An Empirical Study on OECD Countries. Journal of Reviews on Global Economics, 2018, 7, 1-9

xiii. Greenfield, B. Q., Quiroz, B., Rothstein-Fisch, C., \& Trumbull, E. (2003). Bridging cultures between home and school: A guide for teachers with a special focus on Latino families. Mahwah, NJ: Lawrence Erlbaum. 
xiv. Hall, R. (2006). Why do some countries produce so much more output per worker than others? Quarterly Journal of Economics, 114, 83-116.

xv. Harbison, F. H. (1974). Human resource and development in UNESCO. Economics and social aspect of educational planning. IIEP. Paris.

xvi. Harmon, C., Oosterbeek, H. \& Walker, I. (2002). Harmon, C. \& Walker, I. (2002) Estimates of the economic return to schooling for the United Kingdom, American Economic Review,

xvii. 85(5), pp. 1278-1286.

xviii. Kothari, C. R. (2012). Research methodology: Methods \& techniques, Second revised ed. Jaipur (India). New Age International Publishers.

xix. Leedy, P. D., \& Ormrod, J. E. (2001). Practical research: Planning and design (7th ed.). Upper Saddle River, NJ: Prentice Hall.

xx. Makyara, E., Semali, L., Lyamtane, E. \& Ogoti, E. (2019). Exploring parental involvement in the education of their children to combat truancy among pastoralist community secondary schools of north eastern Tanzania. International Journal of Innovative Research and

xxi. Development, Vol. 8, Issue 7, July 2019, ISSN 2278-0211 (Online).

xxii. Murray, J. (2007). The wider social benefits of higher education: What do we know about them?

xxiii. Australian Journal of Education, 53 (3), pp. 230-244.

xxiv. Oppenheim, A.N. (1992). Questionnaire Design and Attitude Measurement, New York: Basic Books.

xxv. Sackey, H. A. \& Harry, A. (2008). Private returns to education in Ghana: Implications for investments in schooling and migration. Malaspina University College Nanaimo, Canada.

xxvi. Schultz, T. W. (1963). The Economic value of Education. Columbia University Press. New York.

xxvii. Sianesi, B. \& Reenen, V. (2003). The returns to education: Macroeconomics. Institute for Fiscal Studies. John Van University College London.

xxviii. Suleman, S. \& Rakesh, R. (2017). The impact of implementation of fee-free education policy on basic education in Tanzania: A qualitative study. Dar es Salaam. HakiElimu

xxix. UNESCO (2006). World data on Education (6Th Ed). Retrieved on 17/ 10/ 2017 from http:/ / www.ibe.unesco.org. xxx. URT, (2015). Education Circular No. 3, 2015. Dodoma. PO - RALG.

xxxi. Zhang, X. (2014). Expected rate of returns on the personal investment in education of no free pre-service students. Chinese Education and society, Vol. 46 No. 2 - 3, 2013. 